\title{
Pengaruh Tingkat Suku Bunga Bank Indonesia Terhadap Pendapatan Margin Murabahah Pada Bank Umum Syariah Di Indonesia Periode 2017-2018
}

\author{
Nurul Imamah ${ }^{1)}$ \\ 1) Institut Agama Islam Negeri Madura, Pamekasan, Indonesia \\ Corresponding author: nurulimamah486@gmail.com
}

\begin{abstract}
:
The development of Islamic Commercial Banks in Indonesia cannot be separated from the development of existing products in Islamic financial institutions. One of the products that dominates in BUS is murabaha. Murabaha is a sale and purchase plus a margin in the selling price. In competition with conventional banks, Islamic banks are supposed to offer lower and competitive margins, but in fact, the margins are actually higher than bank interest rates. Regarding margins, Muhammad stated that one of the factors affecting the size of the margin was the current interest rate.

Based on this, the objectives of this study are firstly: the researcher wants to find out whether there is an effect of Bank Indonesia's interest rate on murabahah margin income at Islamic Commercial Banks in Indonesia in 2017-2018; second: the researcher wants to know how much influence the Bank Indonesia interest rate has on murabahah margin income at Islamic Commercial Banks in Indonesia in 2017-2018. This study uses a quantitative approach, with panel data regression analysis using the Random Effect Model (REM) approach, and data collection through documentation because the data in this study are secondary data. The object in this study is a Sharia Commercial Bank that has met certain criteria so that there are 6 Islamic Commercial Banks. The results of this study indicate that the Bank Indonesia interest rate has an influence on murabahah margin income. This is stated based on the results of the estimation of the random effect model that the Bank Indonesia interest rate variable $(\mathrm{X})$ shows a probability value of $0.0075<0.05$ and an $\mathrm{R}$ square value of 0.049188 . From the test results, the coefficient of determination shows that the independent variable affects the dependent variable by $4.9 \%$ and the remaining $95.1 \%$ is influenced by other variables not examined in this study.
\end{abstract}

Keywords: REM; BI Rates; Murabahah Margin Income

\begin{abstract}
Abstrak:
Perkembangan Bank Umum Syariah di Indonesia tidak lepas dari perkembangan produkproduk yang ada di dalam lembaga keuangan syariah. Salah satu produk yang mendominasi pada BUS ialah murabahah. Murabahah merupakan jual beli yang ditambah dengan margin dalam harga jualnya. Dalam persaingan dengan bank konvensional seharusnya bank syariah menawarkan margin yang lebih rendah dan kompetitif namun pada kenyataannya, margin justru lebih besar dari pada suku bunga perbankan. Berkaitan dengan margin, Muhammad menyatakan bahwa salah satu faktor yang mempengaruhi besarnya margin ialah suku bunga berjalan.

Berdasarkan hal tersebut maka yang menjadi tujuan dalam penelitian ini adalah pertama: peneliti ingin mengetahui adakah pengaruh tingkat suku bunga Bank Indonesia terhadap pendapatan margin murabahah pada Bank Umum Syariah di Indonesia tahun 2017-2018; kedua: peneliti ingin mengetahui seberapa besar pengaruh tingkat suku bunga Bank Indonesia terhadap pendapatan margin murabahah pada Bank Umum Syariah di Indonesia tahun 2017-2018. Penelitian ini menggunakan pendekatan kuantitatif, dengan analisis regresi data panel pendekatan Random Effect Model (REM), dan pengumpulan data melalui dokumentasi karena data dalam penelitian ini berupa data sekunder. Objek dalam penelitian
\end{abstract}


ini adalah Bank Umum Syariah yang telah memenuhi kriteria-kriteria tertentu sehingga berjumlah 6 Bank Umum Syariah. Dari hasil penelitian menunjukkan bahwa tingkat suku bunga Bank Indonesia mempunyai pengaruh terhadap pendapatan margin murabahah. Hal tersebut dinyatakan berdasarkan hasil estimasi random effect model bahwa variabel tingkat suku bunga Bank Indonesia (X) menunjukkan nilai probabilitas $0.0075<0.05$ dan nilai Rsquare sebesar 0.049188. Dari hasil uji koefisien determinasi menunjukkan bahwa variabel independen mempengaruhi variabel dependen sebesar 4,9\% dan sisanya 95,1\% dipengaruhi oleh variabel lain yang tidak diteliti dalam penelitian ini.

Kata Kunci: REM; Suku Bunga Bank Indonesia; Pendapatan Margin Murabahah 


\section{PENDAHULUAN}

Ekonomi syariah sedang mengalami pertumbuhan yang pesat pada saat ini, studi dan konsep mengenai ekonomi syariah tidak hanya dikaji di Negara Muslim, tetapi di Negara yang rata-rata penduduknya non-muslim pun juga banyak yang mengkaji mengenai konsep ekonomi syariah. Semenjak terjadinya krisis di beberapa negara dengan sistem ekonomi kapitalisme, mulai ada pemikiran mengenai sistem ekonomi baru sebagai pengganti dari sistem kapitalisme yang dianggap gagal. Gagalnya sistem ekonomi kapitalisme dipicu oleh adanya sistem bunga yang dirasa jauh dari prinsip keadilan. Adapun salah satu bagian dari ekonomi syariah ialah perbankan syariah. ${ }^{1}$

Di Indonesia sendiri perbankan syariah mulai diperkenalkan pada tahun 1992 saat pemerintah mulai memperkenalkan sistem perbankan ganda dimana bank dapat beroperasi dengan prinsip bagi hasil atau menggunakan prinsip bunga secara bersamaan, hal tersebut tertuang dalam Undang-Undang Perbankan No.7 Tahun 1992 tentang dual banking system.

Penerapan sistem keuangan dan perbankan ganda mulai terarah semenjak dikeluarkannya Undang-Undang Perbankan No.10 Tahun 1998. Semenjak itu, mulailah bermunculan lembaga-lembaga keuangan syariah yang beroperasi berdampingan dengan lembaga keuangan konvensional seperti di Malaysia. Lembaga keuangan syariah di Indonesia juga berkembang menjadi lembaga keuangan alternatif bagi masyarakat yang menginginkan pelayanan jasa keuangan yang sesuai dengan prinsip syariah.

Perkembangan bank syariah di Indonesia sampai Januari 2019 mampu mendirikan 14 BUS (Bank Umum Syariah) sebanyak 1.207 kantor cabang pembantu dengan 477 kantor cabang dan 201 kantor kas yang tersebar di seluruh penjuru Indonesia dan telah tercatat dalam statistik perbankan syariah. ${ }^{2}$

Tabel 1

Bank Umum Syariah

\begin{tabular}{|c|l|c|c|c|}
\hline No & \multicolumn{1}{|c|}{ Bank Umum Syariah } & KPO/KC & KCP/UPS & KK \\
\hline 1 & PT. Bank Aceh Syariah & 26 & 89 & 28 \\
\hline 2 & PT Bank Nusa Tenggara Barat Syariah & 13 & 22 & 4 \\
\hline 3 & PT. Bank Muamalat Indonesia & 82 & 152 & 57 \\
\hline 4 & PT. Bank Victoria Syariah & 9 & 5 & - \\
\hline 5 & PT. Bank BRISyariah & 50 & 206 & 12 \\
\hline 6 & PT. Bank Jabar Banten Syariah & 9 & 55 & 1 \\
\hline 7 & PT. Bank BNI Syariah & 68 & 191 & 17 \\
\hline 8 & PT. Bank Syariah Mandiri & 129 & 429 & 55 \\
\hline 9 & PT. Bank Mega Syariah & 27 & 34 & 7 \\
\hline 10 & PT. Bank Panin Dubai Syariah & 15 & 3 & - \\
\hline 11 & PT. Bank Syariah Bukopin & 12 & 7 & 4 \\
\hline 12 & PT. BCA Syariah & 12 & 12 & 16 \\
\hline 13 & PT. BTPN Syariah & 24 & 2 & - \\
\hline 14 & PT. Maybank Syariah Indonesia & 1 & - &.- \\
\hline
\end{tabular}

Sumber: Otoritas Jasa Keuangan, Statistik Perbankan Syariah (2019)

Perkembangan bank syariah di Indonesia tersebut telah menjadi tolak ukur keberhasilan eksistensi ekonomi syariah. Krisis moneter yang terjadi pada tahun 1998 telah menenggelamkan beberapa bank konvensional dan banyak dilikuidasi karena kegagalan sistem bunganya, sementara perbankan yang menerapkan sistem syariah tetap eksis dan

\footnotetext{
${ }^{1}$ Herni Ali dan M Miftahurrohman, "Analisis Pengaruh Dana Pihak Ketiga (DPK), Non Performing Financing dan Tingkat Suku Bunga Kredit Terhadap Pembiayaan Berbasis Bagi Hasil (Mudharabah) Pada Perbankan Syariah di Indonesia," Tauhidinomics: Journal of Islamic Banking and Economics 1, no. 2 (2015): 151, https://doi.org/10.15408/thd.v1i2.8432.

2 Otoritas Jasa Keuangan, “Statistik Perbankan Syariah 2019,” t.t., https://www.ojk.co.id.
} 
mampu bertahan. Tidak hanya itu, di tengah-tengah krisis keuangan global yang melanda dunia pada akhir tahun 2008, lembaga keuangan syariah kembali membuktikan kekuatannya dari terpaan krisis.

Bank syariah merupakan lembaga keuangan atau perbankan yang operasional dan produknya dikembangkan berlandaskan al-Qur'an dan al-Hadits. ${ }^{3}$ Bank tanpa bunga ini beroperasi sesuai prinsip syariah dengan tidak mengandalkan sistem bunga. Bunga bank sendiri dapat diartikan sebagai balas jasa atau harga yang harus dibayar kepada nasabah yang memiliki simpanan dan harga yang harus dibayar nasabah kepada bank karena telah memperoleh pinjaman. ${ }^{4}$ Sedangkan suku bunga Bank Indonesia merupakan suku bunga kebijakan yang mencerminkan sikap atau stance kebijakan moneter yang diterapkan oleh Bank Indonesia dan diumumkan kepada publik. ${ }^{5}$

Untuk menghindari pengoperasian bank dengan sistem bunga, Islam memperkenalkan prinsip muamalah sebagai salah satu solusi dan alternatif terhadap persoalan antara bunga bank dengan riba. Jadi dapat disimpulkan bahwa bank syariah adalah lembaga keuangan yang kegiatan utamanya menghimpun dana dan memberikan pembiayaan serta jasa-jasa lainnya dalam lalu lintas pembayaran yang pengoperasiannya berlandaskan syariat islam.

Berbeda dengan bank konvensional yang melakukan usaha pembiayaannya menggunakan skema pinjaman, bank syariah justru meramaikan industri perbankan Indonesia menggunakan skema akad seperti mudharabah, musyarakah, murabahah, salam, ijarah, qard dan akad lain yang sesuai dengan syariah. Dari sekian skema akad yang ada, akad murabahah merupakan akad yang paling mendominasi industri perbankan syariah. ${ }^{6}$ Mendominasinya akad murabahah disertai beberapa alasan. Pembiayaan murabahah dinilai lebih minim resikonya dibandingkan dengan pembiayaan bagi hasil karena harga jual dan keuntungan yang ditetapkan di awal akad. Secara operasional terdapat kemiripan antara akad murabahah dengan kredit konsumtif di bank konvensional sehingga masyarakat lebih mengenal akad murabahah dari pada skema akad lainnya. ${ }^{7}$ Syariah.

Berikut merupakan tabel produk pembiayaan yang paling banyak pada Bank Umum

Tabel 1.2

Pembiayaan Bank Umum Syariah

\begin{tabular}{|l|c|c|c|c|}
\hline Akad & $\mathbf{2 0 1 4}$ & $\mathbf{2 0 1 5}$ & $\mathbf{2 0 1 6}$ & $\mathbf{2 0 1 7}$ \\
\hline Murabahah & 86.072 & 87.789 & 105.112 & 110.115 \\
\hline Mudharabah & 8.424 & 7.979 & 7.577 & 6.584 \\
\hline Salam & - & - & - & - \\
\hline musyarakah & 38.501 & 44.419 & 50.546 & 57.315 \\
\hline
\end{tabular}

Sumber: Otoritas Jasa Keuangan, SPS (2017)

\footnotetext{
${ }^{3}$ Muhamad, Manajemen Pembiayaan Bank Syariah (Yogyakarta: UPP STIM YKPN, 2016), 1.

${ }^{4}$ Kasmir, Dasar-dasar Perbankan (Jakarta: Rajawali Press, 2014), 154.

${ }^{5}$ Fifi Hakimi, "Pengaruh FDR, NPF, Biaya Operasional, Inflasi, dan BI Rate Terhadap Margin Pembiayaan Murabahah (Studi Kasus BPRS Bangun Drajat Warga Periode 2019-2016)," Naskah Publikasi, 2017, 11.

${ }^{6}$ Agus Fakhriana, "Pengaruh Suku Bunga Kredit dan Deposito Bank Konvensional Terhadap Margin Pembiayaan Murabahah Bank Syariah di Indonesia," Jurnal Penelitian 2, no. 1 (2015): 41, https://doi.org/10.28918/jupe.v12i1.642.

${ }^{7}$ Rianto Anugerah Wicaksono, "Pengaruh Perubahan Tingkat Suku Bunga Kredit Bank Konvensional dan Tingkat Suku Bunga Bank Indonesia Terhadap Pembiayaan Bank Islam Berbasis Murabahah,” Jurnal Publikasi Manajemen 13, no. 3 (2015): 495, https://jurnaljam.ub.ac.id/index.php/jam/article/view/794.
} 
Berdasarkan tabel di atas, dapat kita ketahui bahwa pembiayaan yang paling sering dilakukan oleh Bank Umum Syariah (BUS) yaitu pembiayaan murabahah yang terus mengalami kenaikan setiap tahunnya. Selanjutnya disusul dengan pembiayaan musyarakah yang juga mengalami kenaikan setiap tahunnya. Sedangkan pembiayaan mudharabah mengalami penurunan setiap tahunnya. Adapun pembiayaan salam realisasinya menjadi tidak ada, setidaknya dilaporkan nihil.

Murabahah sendiri berasal dari kata "Ribh" yang berarti tambahan atau keuntungan. Murabahah merupakan transaksi jual beli suatu barang sebesar harga perolehan barang ditambah dengan margin yang disepakati oleh kedua belah pihak dimana penjual menginformasikan terlebih dahulu harga perolehan kepada pembeli atau nasabah. ${ }^{8}$ Hal yang menjadi unsur dasar murabahah adalah jika si penjual dalam hal ini bank syariah mengungkapkan harga asli barang dengan penambahan keuntungan tertentu atau margin yang boleh dinominalkan ataupun diprosentasekan.

Disamping itu, margin murabahah merupakan selisih antara kelebihan harga jual terhadap harga beli. ${ }^{9}$ Secara teknis, margin keuntungan adalah persentase tertentu yang ditetapkan pertahun misalnya perhitungan margin secara bulanan maka setahun ditetapkan 12 bulan. ${ }^{10}$ Jika kita bandingkan, besar kecilnya bunga yang dibayar oleh nasabah debitur pada dasarnya ditentukan oleh seberapa lama periode pinjaman. Semakin lama jangka waktu maka akan semakin banyak pula bunga yang akan dibayarkan sehingga pada dasarnya esensi bunga adalah tambahan dari pokok hutang. Sedangkan murabahah bukanlah instrumen utang-piutag uang, melainkan sebagai jual-beli.

Produk dengan jenis akad murabahah banyak diminati karena murabahah hampir sama dengan kredit konsumtif yang ada di bank konvensional sehingga masyarakat mudah mengenali pembiayaan murabahah. Akad murabahah juga dinilai sebagai produk yang menguntungkan dengan sasaran masyarakat menengah ke bawah.

Dalam persaingan dengan bank konvensional, seharusnya bank syariah menawarkan margin yang lebih rendah dari pada suku bunga kredit perbankan agar pembiayaan murabahah lebih kompetitif. Namun margin murabahah pada kenyataannya justru lebih besar dari pada suku bunga perbankan. Kecenderungan margin murabahah yang seperti ini didasarkan atas antisipasi dari naiknya suku bunga pasar atau inflasi, sehingga jika terjadi kenaikan suku bunga yang besar maka bank syariah tidak akan mengalami kerugian secara riil. Namun, apabila suku bunga di pasar tetap stabil atau bahkan turun maka margin murabahah akan lebih besar dibandingkan suku bunga pada bank konvensional.11

Berkaitan dengan margin, Karim menyatakan bahwa penetapan margin pembiayaan bank syariah berdasarkan rekomendasi, usulan dan saran dari rapat Tim ALCO (Assets and Loss Committee) bank syariah dengan mempertimbangkan di antaranya Indirect Competitor's Market Rate (ICMR), selain Direct Competitor's Market Rate (DCMR), External Competitive Return For Investors (ECRI), Acquiring Cost, dan Overhead Cost. ICMR adalah tingkat suku bunga rata-rata perbankan konvensional atau tingkat rata-rata suku bunga beberapa bank konvensional yang dalam rapat ALCO ditetapkan sebagai kelompok kompetitor tidak langsung, atau rata-rata suku bunga bank konvensional tertentu yang dalam rapat ALCO ditetapkan sebagai kompetitor tidak langsung yang terdekat.12

Berbeda dengan penelitian yang dilakukan oleh Fifi Hakimi dengan judul penelitian "Pengaruh FDR, NPF, Biaya Operasional, Inflasi, dan BI Rate Terhadap Margin Pembiayaan

\footnotetext{
${ }^{8}$ Muhamad, Manajemen Bank Syariah (Yogyakarta: UPP STIM YKPN, 2018), 123.

${ }^{9}$ Sugeng Widodo, Pembiayaan Murabahah (Yogyakarta: UII Press, 2017), 75.

${ }^{10}$ Adiwarman A. Karim, Bank Islam: Analisis Fiqih Dan Keuangan (Jakarta: PT Raja Grafindo Persada, 2013), 279.

${ }^{11}$ Astri Arumdhani dan Rini Septiani, "Pengaruh Pembiayaan Murabahah Dan Tingkat Suku Bunga BI Terhadap Pendapatan Margin Murabahah Pada PT Bank Syariah Mandiri," Jurnal Riset Akuntansi 4, no. 1 (2012): 25, https://ojs.unikom.ac.id/index.php/jira/article/view/1920.

${ }^{12}$ Karim, Bank Islam: Analisis Fiqih Dan Keuangan, 279.
} 
Murabahah di BPRS Bangun Drajat Warga pada tahun 2017 yang menyatakan bahwa variabel BI Rate tidak berpengaruh terhadap tingkat margin murabahah. Hal ini juga diungkapkan oleh Khiaroh Ekawati dengan judul penelitiannya "Faktor-faktor yang Mempengaruhi Tingkat Margin Murabahah pada Industri Perbankan Syariah Periode 2012-2017 yang menyatakan bahwa faktor atau variabel BI Rate tidak berpengaruh terhadap tingkat margin murabahah sehingga penelitian ini dimaksudkan untuk menguji konsistensi teori yang diungkapkan oleh Adiwarman Karim seperti yang dijelaskan di atas.

Jadi, guna mengetahui apakah ada pengaruh tingkat suku bunga Bank Indonesia terhadap pendapatan margin murbahah pada Bank Umum Syariah di Indonesia, maka dari itu perlu dilakukan penelitian untuk mengetahui pengaruh tersebut. Oleh karena itu, saya tertarik untuk melakukan penelitian yang berjudul "Pengaruh Tingkat Suku Bunga Bank Indonesia Terhadap Pendapatan Margin Murabahah Pada Bank Umum Syariah di Indonesia Periode 2017-2018".

\section{METODE PENELITIAN}

\section{a. Rancangan Penelitian}

Penelitian ini merupakan jenis penelitian yang menggunakan pendekatan kuantitatif yaitu penelitian dengan menggunakan analisis data statistik atau angka-angka. Sedangkan sifat dari penelitian ini adalah kausal, yaitu hubungan yang bersifat sebab akibat, sehingga dalam penelitiannya ada variabel independen dan dependen. Adapun metode penelitian yang digunakan dalam penelitian ini adalah metode kuantitatif karena data dalam penelitian ini berupa angka-angka dan analisis statistik. ${ }^{13}$

Pada penelitian ini variabel yang dilibatkan yaitu variabel $X$ (variabel independen) yaitu suku bunga Bank Indonesia sedangkan variabel $Y$ (variabel dependen) adalah pendapatan margin murabahah. Tujuannya adalah untuk mengetahui pengaruh tingkat suku bunga Bank Indonesia $(\mathrm{X})$ terhadap pendapatan margin murabahah $(\mathrm{Y})$.

\section{b. Populasi dan Sampel}

Populasi adalah keseluruhan objek atau subjek yang berada pada suatu wilayah dan memenuhi syarat-syarat tertentu berkaitan dengan masalah penelitian, atau keseluruhan unit atau individu dalam ruang lingkup yang akan diteliti. ${ }^{14}$ Populasi dalam penelitian ini adalah Bank Umum Syariah (BUS) yang ada di Indonesia yang berjumlah 14 BUS. ${ }^{15}$

Sedangkan sampel adalah bagian dari populasi yang akan diteliti secara mendalam. ${ }^{16}$ Teknik pengambilan sampel dalam penelitian ini menggunakan purposive sampling. Purposive sampling merupakan teknik penentuan sampel yang diambil dengan pertimbangan atau kriteria-kriteria tertentu. ${ }^{17}$

Dengan metode purposive sampling yang dipilih dalam penelitian ini, maka populasi objek dalam penelitian ini adalah 6 Bank Umum Syariah. Bank-bank tersebut antara lain Bank Syariah Bukopin, Bank BNI Syariah, Bank Jabar Banten Syariah, Bank BCA Syariah, Bank Victoria Syariah, dan Bank Maybank Syariah Indonesia.

Sedangkan populasi data dalam penelitian ini berjumlah 144 data yang menggunakan laporan keuangan laba-rugi bulanan bank umum syariah selama 2 periode yaitu dari tahun 2017-2018 ( 2 tahun x 12 bulan x 6 BUS = 144 data).

\footnotetext{
${ }^{13}$ Sugiyono, Metode Penelitian Kuantitatif Kualitatif dan R\&D (Bandung: CV.Alfabeta, 2006), 261.

${ }^{14}$ Nanang Martono, Metode Penelitian Kuantitatif Analisis Isi dan Analisis Data Sekunder (Jakarta: Rajawali Pers, 2011), 74.

15 Otoritas Jasa Keuangan, "Statistik Perbankan Syariah 2019."

${ }^{16}$ Moh Kasiram, Metode Penelitian Kualitatif-Kuantitatif (Malang: UIN Maliki Press, 2010), 257.

${ }^{17}$ V. Wiratna Sejarweni dan Poly Endrayanto, Statistik Untuk Penelitian (Yogyakarta: Graha Ilmu, 2012), 16.
} 


\section{c. Instrumen Penelitian}

Instrumen penelitian adalah alat yang akan digunakan penelitian untuk mengambil, merekam, atau menggali data. Instrumen penelitian yang digunakan dalam penelitian ini berupa dokumentasi yaitu dengan melakukan pencatatan atau mengumpulkan catatancatatan yang menjadi bahan penelitian berupa publikasi laporan keuangan laba rugi bulanan enam Bank Umum Syariah tahun 2017-2018 yang diambil dari website resmi 6 BUS dan data suku bunga Bank Indonesia yang diambil dari website resmi www.bi.go.id.

\section{d. Pengumpulan Data}

Data dalam penelitian ini merupakan data sekunder, data tersebut peneliti peroleh dari laporan keuangan Bank Umum Syariah yang didapat dari website resmi BUS tersebut. Adapun metode yang digunakan dalam penelitian ini ialah sebagai berikut:

\section{Field Research}

Peneliti menggunakan data sekunder berupa data panel (data gabungan dari time series dan data cross section) yang diambil dari laporan keuangan bank syariah dengan skala bulanan selama periode 2017-2018.

\section{Library Research}

Library research merupakan teknik pengumpulan data yang dilengkapi dengan membaca, mempelajari, dan menganalisis literatur yang bersumber dari buku-buku dan jurnal-jurnal yang berkaitan dengan penelitian ini.

\section{Internet Research}

Internet research digunakan dalam penelitian ini karena terkadang buku referensi atau literatur yang peneliti miliki atau pinjam dari perpustakaan merupakan literatur lama, karena ilmu selalu berkembang seiring berjalannya waktu. Oleh karena itu, untuk mengantisipasi kurang update-nya data, peneliti menggunakan teknologi yang juga berkembang yaitu internet sehingga data yang diperoleh merupakan data yang sesuai dan mengikuti perkembangan zaman.

\section{e. Anaisis Data}

Analisis data merupakan proses mengatur urutan data, mengorganisasikannya ke dalam suatu pola, kategori dan satuan uraian dasar. ${ }^{18}$ Penelitian ini menggunakan analisis regresi data panel. Analisis data panel dipilih karena data dalam penelitian ini terdiri dari dua jenis data, yaitu data runtun waktu (time series) dan data silang (cross section) yang dilakukan dengan menggunakan program Eviews 9. Adapun langkah-langkah dalam menganalisis data adalah sebagai berikut:

\section{Mencari Data Mentah}

Data mentah yang diperoleh merupakan data sekunder, yaitu data yang diperoleh dalam bentuk jadi dan telah diolah oleh pihak lain, dikumpulkan dan disatukan oleh studistudi sebelumnya, yang biasanya dalam bentuk publikasi. ${ }^{19}$ Data sekunder dalam penelitian ini berupa publikasi laporan laba rugi bulanan Bank Umum Syariah periode 2017-2018.

\section{Analisis Statitik Deskriptif}

Pada penelitian ini statistik deskriptif bertujuan untuk memberikan gambaran deskripsi mengenai variabel penelitian pengaruh tingkat suku bunga Bank Indonesia terhadap pendapatan margin murabahah. Analisis statistik deskriptif yang digunakan yaitu:
a) Mean
b) Maximum
c) Minimum
d) Standar Deviation

\footnotetext{
${ }^{18}$ Iqbal Hasan, Analisis Data Penelitian Dengan Statistik (Jakarta: PT Bumi Aksara, 2010), 29.

${ }^{19}$ Fatati Nuryana, Statistik Bisnis Jilid I (Surabaya: Pena Salsabila, 2013), 20.
} 


\section{Uji Asumsi Klasik}

Uji asumsi klasik dilakukan untuk menilai baik tidaknya model regresi yang digunakan dalam penelitian. Ada beberapa uji statistik yang diterapkan mulai dari yang paling sederhana sampai yang paling kompleks. Adapun uji asumsi klasik yang digunakan dalam penelitian ini antara lain:

\section{a) Uji Normalitas}

Uji normalitas bertujuan untuk mengetahui apakah distribusi sebuah data mengikuti atau mendekati distribusi normal. Jika data ternyata tidak berdistribusi normal, maka analisis nonparametik dapat digunakan. Namun jika data berdistribusi normal, maka analisis parametik termasuk model-model regresi dapat digunakan. ${ }^{20}$ Uji normalitas dalam penelitian ini yaitu menggunakan uji P-Plot dan Kolmogorov-Smirnov.

\section{b) Uji Heteroskedastisitas}

Uji heteroskedastisitas bertujuan untuk melihat apakah terdapat ketidaksamaan varians dari residual satu pengamatan ke pengamatan yang lain. ${ }^{21}$ Uji heteroskedastisitas dalam penelitian ini menggunakan uji glejser dengan program SPSS 20.

\section{c) Uji Autokorelasi}

Uji autokorelasi ini bertujuan untuk menguji apakah dalam model regresinya ada korelasi antara kesalahan pengganggu pada periode $t$ dengan kesalahan pada periode $t-1$ (sebelumnya). ${ }^{22}$ Untuk memeriksa adanya autokorelasi, dalam penelitian ini menggunakan uji Durbin-Watson.

\section{Analisis Regresi Data Panel}

Data panel merupakan gabungan antara data time series (runtut waktu) dan data cross section (data silang). Data panel pertama kali diperkenalkan oleh Howles pada tahun 1950. Data runtut waktu biasanya meliputi satu objek (misalnya harga saham, kurs mata uang, atau tingkat inflasi), tetapi meliputi beberapa periode (harian, bulanan, kuartalan, tahunan, dan sebagainya). ${ }^{23}$

Sedangkan data silang terdiri atas beberapa banyak objek, sering disebut responden (misalnya perusahaan) dengan beberapa jenis data (misalnya laba, biaya iklan, laba ditahan dan tingkat investasi).

\section{Estimasi Model Data Panel}

Menurut Nachrowi, untuk mengestimasi parameter model dengan data panel, terdapat beberapa teknik yang bisa dipakai, yaitu Pooled Least Square (PLS), Fixed Effect Model (FEM) dan Random Effect Model (REM). ${ }^{24}$

\section{a) Pooled Least Square (PLS)}

Teknik PLS ini sama halnya dengan membuat regresi dengan data cross section atau time series. Akan tetapi, untuk data panel, sebelum membuat regresi kita harus menggabungkan data cross section dengan time series (pool data). Lalu data gabungan ini diperlakukan sebagai satu kesatuan pengamatan yang digunakan untuk mengestimasi model dengan model PLS.

\section{b) Fixed Effect Model (FEM)}

Adanya variabel-variabel yang tidak semuanya masuk dalam persamaan model memungkinkan adanya intercept ini mungkin berubah setiap individu dan waktu. Pemikiran inilah yang menjadi dasar pemikiran pembentukan model fixed effect.

\footnotetext{
${ }^{20}$ Singgih Santoso, Statistik Multivariat (Jakarta: PT Elex Media Komputindo, 2010), 43.

${ }^{21}$ Albert Kurniawan, Metode Riset Untuk Ekonomi \& Bisnis (Bandung: Alfabeta, 2014), 158.

${ }^{22}$ Husein Umar, Metode Penelitian untuk Skripsi dan Tesis Bisnis (Jakarta: Rajawali Pers, 2013), 143.

${ }^{23}$ Badi H Baltagi, Econometric Analysis of Panel Data, 3 ed. (Southern Gate: John Wiley \& Sons, 2005), 4.

${ }^{24}$ Nachrowi N Djalal dan Hardius Usman, Pendekatan Populer dan Praktis Ekonomi dan Keuangan (Jakarta: LPFE Universitas Indonesia, 2006), 316.
} 
Asumsi pembuatan model yang menghasilkan $\alpha$ konstan untuk setiap individu (i) dan waktu (t) kurang realistis. Dalam Fixed Effect Model (FEM) ini kita dapat mengatasi hal tersebut, karena metode ini memungkinkan adanya perubahan $\alpha$ pada setiap i dan $t$.

\section{c) Random Effect Model (REM)}

Jika pada model Fixed Effect perbedaan antar individu atau waktu dicerminkan lewat intercept, maka pada model Random Effect, perbedaan tersebut diakomodasi melalui error. Teknik ini juga memperhitungkan bahwa error mungkin berkorelasi sepanjang times series dan cross section. $^{25}$

\section{Pemilihan Metode Dalam Data Panel}

Pada dasarnya ketiga teknik (model) estimasi data panel dapat dipilih sesuai dengan keadaan penelitian, dilihat dari jumlah individu bank dan variabel penelitiannya. Namun demikian ada beberapa cara yang dapat digunakan untuk menentukan teknik mana yang paling tepat dalam mengestimasi parameter data panel. Menurut Widarjono, ada tiga uji untuk memilih teknik estimasi data panel. Pertama, uji statistik F digunakan untuk memilih antara metode Common Effect (Pooled Least Square) atau metode Fixed Effect. Kedua, uji Hausman yang digunakan untuk memilih antara metode Fixed Effect atau metode Random Effect. Ketiga, uji Langrange Multiplier (LM) yang digunakan untuk memilih metode Random Effect atau Common Effect. ${ }^{26}$

Sedangkan menurut Nachrowi, untuk menentukan model data panel yang dipilih, diperlukan pengujian beberapa tahap, yaitu:27

\section{a) Uji Statistik F (Uji Chow)}

Uji digunakan untuk mengetahui apakah teknik regresi data panel dengan metode Fixed Effect lebih baik dari regresi model data panel dengan metode Common Effect.

Adapun Hipotesis dalam uji chow ini ialah:

Ho: model yang tepat untuk regresi data panel adalah Common Effect

Ha: model yang tepat untuk regresi data panel adalah Fixed Effect. berikut:

Adapun kesimpulan yang dapat diambil dari uji Statistik F (uji Chow) ini ialah sebagai

1) Apabila nilai probabilitas cross section $\mathrm{F}<0,05=$ tolak Ho (artinya, model yang tepat untuk regresi data panel adalah model Fixed Effect)

2) Apabila nilai probabilitas cross section $\mathrm{F}>0,05=$ terima Ho (artinya, model yang tepat untuk regresi data panel adalah model Common Effect atau PLS).

\section{b) Uji Hausman}

Uji Hausman digunakan untuk memilih apakah model Fixed Effect lebih baik dari metode Random Effect.

Hipotesis dalam uji Hausman ialah sebagai berikut:

Ho: model yang tepat adalah Random Effect

Ha: model yang tepat adalah Fixed Effect

Adapun kesimpulan yang dapat diambil dalam uji Hausman ini adalah:

1) Jika probabilitas $<0,05=$ tolak Ho

Artinya, model regresi panel data yang tepat adalah model Fixed Effect.

2) Jika probabilitas $>0,05=$ terima Ho

Artinya, model regresi panel data yang tepat adalah model Random Effect.

c) Uji Langrange Multiplier

Uji ini dilakukan untuk mengetahui apakah model Random Effect lebih baik dari pada model Common Effect.

\footnotetext{
${ }^{25}$ Djalal dan Usman, 317.

${ }^{26}$ Agus Widarjono, Ekonometrika: Teori dan Aplikasi Untuk Ekonomi dan Bisnis Edisi Kedua (Yogyakarta: Ekonisia FE Universitas Islam Indonesia, 2007), 258.

${ }^{27}$ Djalal dan Usman, Pendekatan Populer dan Praktis Ekonomi dan Keuangan, 318.
} 
Hipotesis dalam uji Langrange Multiplier ini sebagai berikut:

Ho : model yang tepat adalah Random Effect

Ha : model yang tepat adalah Common Effect

Adapun kesimpulan yang dapat diambil pada uji LM ialah:

1) Jika Cross section Breusch Pagan $>0,05=$ tolak Ho

Artinya, model regresi data panel yang tepat adalah Common Effect

2) Jika Cross section Breusch Pagan < 0,05 = terima Ho

Artinya, model regresi data panel yang tepat adalah Random Effect ${ }^{28}$

\section{Uji Hipotesis}

\section{a) Uji t (Parsial)}

Uji ini digunakan untuk mengetahui pengaruh variabel independen yang dimasukkan dalam model regresi secara individual terhadap variabel dependen. Uji t-statistik dapat diselesaikan dengan menggunakan rumus:

$$
\mathrm{ti}=\frac{\mathrm{bj}}{\mathrm{Sbj}}
$$

keterangan:

ti : nilai t hitung

bj : Koefisien regresi

Sbj : Kesalahan baku koefisien regresi

Adapun hipotesis dalam uji-t ialah sebagai berikut:

Ho : Tidak ada pengaruh dari tingkat suku bunga Bank Indonesia tidak terhadap pendapatan margin murabahah pada Bank Umum Syariah di Indonesia.

Ha : Terdapat pengaruh dari tingkat suku bunga Bank Indonesia terhadap pendapatan margin murabahah pada Bank Umum Syariah di Indonesia.

Sedangkan dasar pengambilan keputusan ialah sebagai berikut:

Jika menggunakan Analisis regresi linier sederhana di program SPSS

1) Apabila nilai $t$ hitung $>t$ tabel dengan signifikan di bawah $0,05(5 \%)$, maka secara parsial atau individual variabel bebas berpengaruh signifikan terhadap variabel terikat atau Ha ditolak dan Ho diterima.

2) Apabila nilai $t$ hitung $<\mathrm{t}$ tabel dengan signifikan di bawah 0,05 (5\%), maka secara parsial atau individual variabel bebas berpengaruh signifikan terhadap variabel terikat atau Ha diterima dan Ho ditolak.

Jika menggunakan regresi data panel di program E-Views

1) Jika probabilitas variabel $X<0,05$ maka tolak Ho

2) Jika probabilitas variabel $X>0.05$ maka terima Ho

\section{b) Koefisien Determinasi}

Koefisien determinasi merupakan bagian dari keragaman total variabel terikat $Y$ yang dapat diterangkan atau diperhitungkan oleh keragaman variabel bebas X. Jadi, koefisien determinasi adalah kemampuan variabel $\mathrm{X}$ mempengaruhi varibel $\mathrm{Y}$, semakin besar koefisien determinasi menunjukkan semakin baik variabel X menerangkan variabel Y.

Pada penelitian ini akan menunjukkan dan menjelaskan hasil berkenaan seberapa besar pengaruh variabel $\mathrm{X}$ (tingkat suku bunga Bank Indonesia) terhadap variabel $\mathrm{Y}$ (pendapatan margin murabahah). Koefisien determinasi digunakan untuk mengukur seberapa jauh kemampuan model dalam menerangkan variasi variabel terikat. Sehingga koefisien determinasi adalah kemampuan variabel $\mathrm{X}$ dalam mempengaruhi variabel $\mathrm{Y}$,

${ }^{28}$ Djalal dan Usman, 321. 
semakin besar koefisien determinasi menunjukkan semakin baik variabel X menerangkan variabel Y.

Jika nilai R2 mendekati nol, maka pengaruh variabel bebas terhadap variabel terikat adalah kecil, sedangkan jika nilai R2 mendekati satu, maka pengaruh variabel bebas terhadap variabel terikat adalah besar.Secara statistik, koefisien determinasi dianggap sebagai korelasi pangkat dua:

$$
\mathrm{R} 2=(\text { korelasi }) 2 \text { atau } \mathrm{R} 2=\mathrm{r} 2
$$

\section{HASIL DAN PEMBAHASAN}

Dari penelitian "Pengaruh Tingkat Suku Bunga Bank Indonesia Terhadap Pendapatan Margin Murabahah Bank Umum Syariah di Indonesia Periode 2017-2018" diperolehinformasi secara umum sebagai berikut:.

Tabel 1.3

Hasil Uji Analisis Statistik Deskriptif

\begin{tabular}{|l|c|c|}
\hline \multicolumn{3}{|c|}{ Date: 01/31/20 Time: 22:57 } \\
\hline \multicolumn{3}{|c|}{ Sample: 2017M01 2018M12 } \\
\hline Mean & $\mathrm{X}$ & $\mathrm{Y}$ \\
\hline Median & 4.822917 & $2.79 \mathrm{E}+11$ \\
\hline Maximum & 4.750000 & $8.83 \mathrm{E}+10$ \\
\hline Minimum & 4.2500000 & $2.21 \mathrm{E}+12$ \\
\hline Std. Dev. & 0.586022 & $1.21 \mathrm{E}+09$ \\
\hline Skewness & 0.783942 & 2.476266 \\
\hline Kurtosis & 2.320498 & 8.358748 \\
\hline & & \\
\hline Jarque-Bera & 17.51990 & 319.4625 \\
\hline Probability & 0.000157 & 0.000000 \\
\hline & & \\
\hline Sum & 694.5000 & $4.01 \mathrm{E}+13$ \\
\hline Sum Sq. Dev. & 49.10938 & $3.32 \mathrm{E}+25$ \\
\hline \multicolumn{2}{|c|}{} & 144 \\
\hline Observations & 144 & 140 \\
\hline
\end{tabular}

Sumber: Output E-Views 9.0 (data sekunder diolah)

Berdasarkan tabel di atas menunjukkan bahwa jumlah data yang digunakan dalam penelitian ini sebanyak 144 data yang diambil dari publikasi laporan keuangan laba rugi Bank Umum Syariah dan tingkat suku bunga Bank Indonesia (BI Rate) dari bulan Januari 2017 hingga bulan Desember tahun 2018.

\section{a. Tingkat Suku Bunga Bank Indonesia}

Berdasarkan tabel 1.3 hasil uji statistik deskriptif diketahui bahwa nilai minimum tingkat suku bunga Bank Indonesia sebesar 4,25\%, nilai maksimum sebesar $6 \%$ dengan nilai ratarata 4,82 sedangkan standar deviasi (std. deviation) sebesar 0.586022 lebih kecil dibandingkan dengan nilai rata-rata sehingga dapat disimpulkan bahwa simpangan data pada variabel tingkat suku bunga Bank Indonesia baik.

\section{b. Pendapatan Margin Murabahah}

Berdasarkan tabel dari hasil uji statistik deskriptif di atas dapat diketahui bahwa nilai minimum dari pendapatan margin murabahah sebesar 1.21E+09 (satu milyar dua ratus sepuluh juta) sedangkan nilai maksimumnya sebesar $2.21 \mathrm{E}+12$ (dua triliun dua puluh satu milyar). Adapun nilai rata-rata menunjukkan 5.98E+11 (lima ratus sembilan puluh delapan milyar) $2.79 \mathrm{E}+11$ (dua ratus tujuh puluh sembilan milyar) dengan standar deviasi sebesar 9.19E+11 (sembilan milyar). 
Grafik 1.1

Hasil Uji P-Plot

Histogram

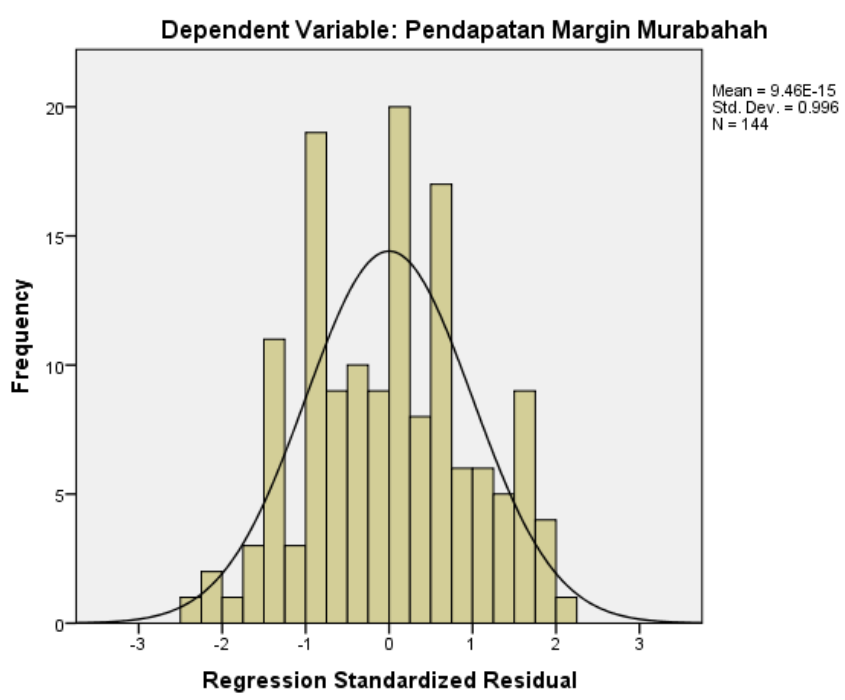

Sumber: Output SPSS 20 (data diolah)

Grafik 1.2

Hasil Uji Normalitas P-Plot

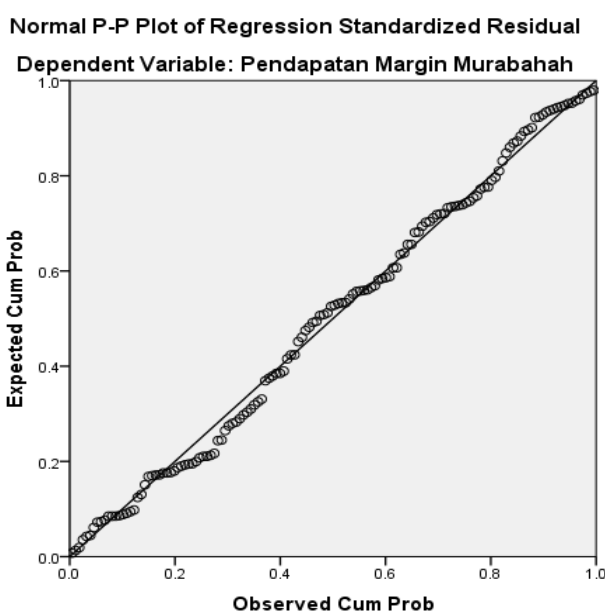

Sumber: Output SPSS 20 (data diolah)

Berdasarkan grafik hasil uji normalitas dengan uji pbobability plot (P Plot), hasilnya titik-titik data menyebar di sekitar garis diagonal dan mengikuti arah garis diagonal sehingga dapat disimpulkan bahwa data berdistribusi normal. Selain menggunakan uji P-Plot, peneliti juga menggunakan uji Kolmogorov-Smirnov agar lebih menggambarkan kenormalan data.

Adapun hasil dari uji Kolmogorov-Smirnov dengan menggunakan SPSS 20 ialah sebagai berikut: 
Tabel 1.4

Hasil Uji Kolmogorov-Smirnov

One-Sample Kolmogorov-Smirnov Test

\begin{tabular}{|ll|r|r|}
\hline & & BI Rate & \multicolumn{1}{c|}{$\begin{array}{c}\text { Pendapatan } \\
\text { Margin } \\
\text { Murabahah }\end{array}$} \\
\hline $\mathrm{N}$ & Mean & 14.8229 & 144 \\
Normal Parameters ${ }^{\mathrm{a}, \mathrm{b}}$ & Std. & .58602 & .74029 \\
& Deviation & .258 & .065 \\
Most Extreme & Absolute & .258 & .065 \\
Differences & Positive & -.164 & -.045 \\
Kolmogorov-Smirnov Z & Negative & 3.094 & .775 \\
Asymp. Sig. (2-tailed) & & .000 & .585 \\
\hline
\end{tabular}

a. Test distribution is Normal.

b. Calculated from data.

Sumber: Output SPSS 20 (data diolah)

Dari tabel di atas, untuk melihat apakah data berdistribusi normal atau tidak, kita bisa melihat di nilai Asymp. Sig. (2-tailed), apabila kedua variabel baik X ataupun Y bernilai lebih kecil dari 0,05 $(<0,05)$, hal ini menandakan bahwa data tidak berdistribusi normal. Akan tetapi, jika salah satu dari variabel X maupun Y memiliki nilai Asymp. Sig. (2-tailed) lebih besar dari 0,05 $(>0,05)$ maka dapat disimpulkan bahwa data berdistribusi normal dan penelitian ini dapat dilanjutkan.

Tabel 1.5

Hasil Uji Durbin-Watson

Model Summaryb

\begin{tabular}{|l|r|r|r|r|r|}
\hline Model & \multicolumn{1}{|c|}{$\mathrm{R}$} & R Square & $\begin{array}{c}\text { Adjusted R } \\
\text { Square }\end{array}$ & $\begin{array}{c}\text { Std. Error of } \\
\text { the Estimate }\end{array}$ & $\begin{array}{c}\text { Durbin- } \\
\text { Watson }\end{array}$ \\
\hline 1 & $.118^{\mathrm{a}}$ & .014 & .007 & .73766 & .857 \\
\hline
\end{tabular}

a. Predictors: (Constant), BI Rate

b. Dependent Variable: Pendapatan Margin Murabahah

Sumber: Output SPSS 20 (data sekunder diolah)

Berdasarkan tabel hasil uji autokorelasi menggunakan uji Durbin-Watson diperoleh nilai DW (Durbin Watson) sebesar 0,857. Sedangkan pada tabel Durbin Watson dengan nilai signifikan 5\%, $\mathrm{n}=144$ dan jumlah variabel independen $1(\mathrm{k}=1)$ adalah $\mathrm{dL}=1.713$ dan $\mathrm{dU}$ sebesar 1.741. Apabila nilai 0,857 < 1.4347 (DW < dL), maka dapat disimpulkan bahwa hasil dari uji DW terdapat autokorelasi positif.

Karena terdapat atokorelasi, maka diperlukan uji lain untuk mengatasi masalah autokorelasi tesebut. Dalam penelitian ini, untuk mengatasi masalah adanya autokorelasi, peneliti menggunakan uji Cochrane-Orcutt dengan mencari nilai Lag terlebih dahulu dari masing-masing variabel kemudian mencari nilai DW kembali.. berikut:

Adapun hasil dari uji Cochrane-orcutt dengan menggunakan uji SPSS versi 20 sebagai 
Tabel 1.6

Hasil Uji Cochrane-Orcutt

Model Summaryb

\begin{tabular}{|l|r|r|r|r|r|}
\hline Model & \multicolumn{1}{|c|}{$\mathrm{R}$} & R Square & $\begin{array}{c}\text { Adjusted R } \\
\text { Square }\end{array}$ & $\begin{array}{c}\text { Std. Error of } \\
\text { the Estimate }\end{array}$ & $\begin{array}{c}\text { Durbin- } \\
\text { Watson }\end{array}$ \\
\hline 1 & $.335^{\mathrm{a}}$ & .112 & .106 & .38705 & 1.887 \\
\hline
\end{tabular}

a. Predictors: (Constant), LAG_X

b. Dependent Variable: LAG_Y

Sumber: Output SPSS 20 (data sekunder diolah)

Tabel 1.7

Pengujian Pengambilan Keputusan DW

\begin{tabular}{|c|c|c|c|c|c|}
\hline $\mathbf{d}_{\mathbf{L}}$ & $\mathbf{d}_{\mathbf{U}}$ & $\mathbf{4 - d _ { \mathbf { L } }}$ & $\mathbf{4 - d _ { \mathbf { U } }}$ & $\mathbf{D W}$ & \multicolumn{1}{|c|}{ Keputusan } \\
\hline 1.713 & 1.741 & 2.287 & 2.259 & 1.887 & $\begin{array}{l}\text { Tidak terjadi autokorelasi } \\
\text { positif maupun negative }\end{array}$ \\
\hline
\end{tabular}

Sumber: Tabel Durbin-Watson

Berdasarkan tabel 1.6 dan 1.7 hasil uji Cochrane-orcutt dan pengujian pengambilan keputusan DW diperoleh nilai DW (Durbin Watson) sebesar 1,887. Sedangkan pada tabel Durbin Watson dengan nilai signifikan 5\%, n=144 dan jumlah variabel independen $1(\mathrm{k}=1)$ adalah $\mathrm{dL}=1.713$ dan $\mathrm{dU}=1.741$. Apabila nilai $1.741<1.887<2.259(\mathrm{dU}<\mathrm{DW}<4-\mathrm{dU})$, maka dapat disimpulkan bahwa hasil dari uji Cochrane-orcutt tidak terdapat autokorelasi.

Tabel 1.8

Hasil Uji Glejser

Coefficients ${ }^{a}$

\begin{tabular}{|c|c|c|c|c|c|}
\hline \multirow[t]{2}{*}{ Model } & \multicolumn{2}{|c|}{ Unstandardized Coefficients } & \multirow{2}{*}{$\begin{array}{c}\text { Standardized } \\
\text { Coefficients }\end{array}$} & \multirow[t]{2}{*}{$\mathrm{t}$} & \multirow[t]{2}{*}{ Sig. } \\
\hline & B & Std. Error & & & \\
\hline (Constant) & $\begin{array}{r}2125447527 \\
66.223\end{array}$ & $\begin{array}{r}1503263782 \\
37.137\end{array}$ & & 1.414 & .160 \\
\hline BI Rate & $\begin{array}{r}- \\
1504355397 \\
9.763\end{array}$ & $\begin{array}{r}3094317093 \\
6.620\end{array}$ & -.041 & -.486 & .628 \\
\hline
\end{tabular}

a. Dependent Variable: RES2

Sumber: Output SPSS 20 (data sekunder diolah)

Berdasarkan tabel hasil uji heteroskedastisitas menggunakan uji glejser di atas diketahui besar nilai signifikansi (Sig) sebesar 0,628 lebih besar dari 0,05 (sig > 0,05), ini berarti bahwa tidak terjadi heteroskedastisitas. 
Tabel 1.9

Hasil Random Effect Model

\begin{tabular}{|c|c|c|c|c|}
\hline \multicolumn{4}{|c|}{ Dependent Variable: PENDAPATAN? } & \\
\hline \multicolumn{5}{|c|}{ Method: Pooled EGLS (Cross-section random effects) } \\
\hline \multicolumn{3}{|c|}{ Date: $03 / 03 / 20$ Time: $16: 44$} & & \\
\hline \multicolumn{3}{|c|}{ Sample: 2017M01 2018M12 } & & \\
\hline \multicolumn{3}{|c|}{ Included observations: 24} & & \\
\hline \multicolumn{3}{|c|}{ Cross-sections included: 6} & & \\
\hline \multicolumn{4}{|c|}{ Total pool (balanced) observations: 144} & \\
\hline \multicolumn{5}{|c|}{ Swamy and Arora estimator of component variances } \\
\hline Variable & $\begin{array}{r}\text { Coefficien } \\
\mathrm{t} \\
\end{array}$ & Std. Error & t-Statistic & Prob. \\
\hline $\mathrm{C}$ & $2.08 \mathrm{E}+11$ & $2.54 \mathrm{E}+11$ & -0.819050 & 0.4141 \\
\hline BIRATE? & $1.01 \mathrm{E}+11$ & $3.73 \mathrm{E}+10$ & 2.710368 & 0.0075 \\
\hline \multicolumn{5}{|l|}{$\begin{array}{c}\text { Random Effects } \\
\text { (Cross) }\end{array}$} \\
\hline _BUKOPIN-C & $1.75 \mathrm{E}+11^{-}$ & & & \\
\hline BCA-C & $1.74 \mathrm{E}+11$ & & & \\
\hline _VICTORIA-C & $2.58 \mathrm{E}+11$ & & & \\
\hline BNI-C & $8.67 \mathrm{E}+11$ & & & \\
\hline _MAYBANK-C & $2.58 \mathrm{E}+11$ & & & \\
\hline \multirow[t]{3}{*}{-BJB-C } & $2.42 \mathrm{E}+09$ & & & \\
\hline & Effects $S_{1}$ & ification & & \\
\hline & & & S.D. & Rho \\
\hline \multicolumn{3}{|l|}{ Cross-section random } & $4.38 \mathrm{E}+11$ & 0.7379 \\
\hline \multicolumn{3}{|l|}{ Idiosyncratic random } & $2.61 \mathrm{E}+11$ & 0.2621 \\
\hline & \multicolumn{2}{|c|}{ Weighted Statistics } & & \\
\hline R-squared & 0.049188 & \multicolumn{2}{|c|}{ Mean dependent var } & $\begin{array}{r}3.36 \mathrm{E}+1 \\
0\end{array}$ \\
\hline Adjusted R-squared & 0.042493 & \multicolumn{2}{|c|}{ S.D. dependent var } & $\begin{array}{r}2.67 \mathrm{E}+1 \\
1\end{array}$ \\
\hline S.E. of regression & $2.61 \mathrm{E}+11$ & \multicolumn{2}{|c|}{ Sum squared resid } & $\begin{array}{r}9.68 \mathrm{E}+2 \\
4\end{array}$ \\
\hline F-statistic & 7.346095 & \multicolumn{2}{|c|}{ Durbin-Watson stat } & $\begin{array}{r}0.49866 \\
5\end{array}$ \\
\hline \multirow[t]{2}{*}{ Prob(F-statistic) } & 0.007550 & & & \\
\hline & \multicolumn{2}{|c|}{ Unweighted Statistics } & & \\
\hline R-squared & 0.015077 & \multicolumn{2}{|c|}{ Mean dependent var } & $2.79 \mathrm{E}+1$ \\
\hline Sum squared resid & $3.27 \mathrm{E}+25$ & \multicolumn{2}{|c|}{ Durbin-Watson stat } & $\begin{array}{r}0.14755 \\
1\end{array}$ \\
\hline
\end{tabular}

Sumber: Output E-Views 9.0 
Setelah dilakukan uji chow, uji hausman, dan uji langrangge multiplier terhadap ketiga model estimasi (Cammon Effect Model, Fixed Effect Model, dan Random Effect Model), hasil yang diperoleh adalah menggunakan Random Effect Model. Jadi, dalam penelitian ini, model estimasi yang paling cocok digunakan adalah Random Effect Model.

Selanjutnya, Random Effect Model akan dianalisis untuk melihat bagaimana hubungan antara variabel dependen dan variabel independen.

Tabel di atas dapat direprentasikan sebagai berikut:

Estimation Command:

$\mathrm{LS}(\mathrm{CX}=\mathrm{R})$ PENDAPATAN? BIRATE?

Estimation Equations:

$$
\begin{aligned}
& ================== \\
& \text { PENDAPATAN_BUKOPIN }=\mathrm{C}(3)+\mathrm{C}(1)+\mathrm{C}(2) * \text { BIRATE_BUKOPIN } \\
& \text { PENDAPATAN_BCA }=\mathrm{C}(4)+\mathrm{C}(1)+\mathrm{C}(2) * \text { BIRATE_BCA } \\
& \text { PENDAPATAN_VICTORIA }=\mathrm{C}(5)+\mathrm{C}(1)+\mathrm{C}(2) * \text { BIRATE_VICTORIA } \\
& \text { PENDAPATAN_BNI }=\mathrm{C}(6)+\mathrm{C}(1)+\mathrm{C}(2) * \text { BIRATE_BNI } \\
& \text { PENDAPATAN_MAYBANK }=\mathrm{C}(7)+\mathrm{C}(1)+\mathrm{C}(2) * \text { BIRATE_MAYBANK } \\
& \text { PENDAPATAN_BJB }=\mathrm{C}(8)+\mathrm{C}(1)+\mathrm{C}(2) * \text { BIRATE_BJB } \\
& \text { Substituted Coefficients: } \\
& ================= \\
& \text { PENDAPATAN_BUKOPIN }=-174865690132-208397396914+ \\
& 100968871354 * \text { BIRATE_BUKOPIN }
\end{aligned}
$$

PENDAPATAN_BCA $=-173700925177-208397396914+$ 100968871354*BIRATE_BCA

PENDAPATAN_VICTORIA $=-258263238602-208397396914+$ 100968871354*BIRATE_VICTORIA

PENDAPATAN_BNI $=866989955161$ - $208397396914+100968871354 *$ BIRATE_BNI

PENDAPATAN_MAYBANK $=-257741911027-208397396914+$ 100968871354*BIRATE_MAYBANK

PENDAPATAN_BJB $=-2418190222.68$ - $208397396914+$ 100968871354*BIRATE_BJB

Berdasarkan tabel 1.9 hasil dari estimasi Random Effect Model, adapun hasil yang dapat diinterpretasikan sebagai berikut:

\section{a) Persamaan Regresinya:}

$$
\begin{array}{cl}
\mathrm{Y} & =\beta \mathrm{X}+\alpha \\
\text { Pendapatan margin murabahah } & =100968871354 * \text { BIRATE }-208397396914
\end{array}
$$


Hasil model regresi data panel dengan pendekatan REM menunjukkan nilai X adalah positif, hal ini berarti:

1) Apabila $X$ naik maka $Y$ juga akan naik.

2) Jika X bernilai 0, maka Y bernilai 208397396914 (208.397.396.914 = dua ratus delapan miliar tiga ratus sembilan puluh tujuh juta tiga ratus sembilan puluh enam ribu sembilan ratus empat belas rupiah).

3) Koefisien estimasi X terhadap Y sebesar 100968871354 (100.968.871.354 = seratus miliar sembilan ratus enam puluh delapan juta delapan ratus tujuh puluh satu ribu tiga ratus lima puluh empat rupiah). Hal ini berarti setiap kenaikan 1\% tingkat suku bunga bank Indonesia akan meningkatkan pendapatan margin murabahah sebesar 100968871354, begitupun jika nilai X turun sebesar 100968871354 satu-satuan maka nilai Y akan turun sebesar 100968871354.

\section{b) Persamaan Regresi setiap BUS}

1) Bank Syariah Bukopin

Pendapatan_Bukopin $=\mathrm{C}(3)+\mathrm{C}(1)+\mathrm{C}(2) *$ Birate_Bukopin

Pendapatan_Bukopin = $100968871354 *$ Birate_Bukopin -174865690132 208397396914.

2) Bank BCA Syariah

Pendapatan_BCA $=\mathrm{C}(4)+\mathrm{C}(1)+\mathrm{C}(2) *$ Birate_BCA

Pendapatan_BCA $=100968871354 *$ Birate_BCA -173700925177 - 208397396914.

3) Bank Victoria Syariah

Pendapatan_Victoria $=\mathrm{C}(5)+\mathrm{C}(1)+\mathrm{C}(2) *$ Birate_Victoria

Pendapatan_Victoria $=100968871354 *$ Birate_Victoria -258263238602 208397396914

4) Bank BNI Syariah

Pendapatan_BNI $=\mathrm{C}(6)+\mathrm{C}(1)+\mathrm{C}(2)^{*}$ Birate_BNI

Pendapatan_BNI $\quad=\quad 866989955161 \quad-\quad 208397396914$

100968871354*Birate_BNI

5) Bank Maybank Syariah Indonesia

Pendapatan_Maybank $=\mathrm{C}(7)+\mathrm{C}(1)+\mathrm{C}(2) *$ Birate_Maybank

Pendapatan_Maybank = 100968871354*Birate_Maybank -257741911027 208397396914

6) Bank Jabar Banten Syariah

Pendapatan_BJB $=\mathrm{C}(8)+\mathrm{C}(1)+\mathrm{C}(2) *$ Birate_BJB

208397396914

Pendapatan _BJB = 100968871354*Birate_BJB - 2418190222.68 -

Tabel 1.10

Hasil Uji t

\begin{tabular}{|c|}
\hline \multirow{2}{*}{ Dependent Variable: PENDAPATAN? } \\
\hline \\
\hline Date: $03 / 03 / 20$ Time: $16: 44$ \\
\hline Sample: 2017M01 2018M12 \\
\hline Included observations: 24 \\
\hline Cross-sections included: 6 \\
\hline Total pool (balanced) observations: 144 \\
\hline
\end{tabular}




\begin{tabular}{|c|r|r|r|r|}
\hline Variable & $\begin{array}{r}\text { Coefficien } \\
\mathrm{t}\end{array}$ & Std. Error & t-Statistic & Prob. \\
\hline C & - & $2.54 \mathrm{E}+11$ & -0.819050 & 0.4141 \\
\hline BIRATE? & $1.01 \mathrm{E}+11$ & $3.73 \mathrm{E}+10$ & 2.710368 & 0.0075 \\
\hline $\begin{array}{c}\text { Random Effects } \\
\text { (Cross) }\end{array}$ & & & & \\
\hline _BUKOPIN-C & - & & \\
\hline _BCA-C & $1.75 \mathrm{E}+11$ & & \\
\hline _VICTORIA-C & $-2.58 \mathrm{E}+11$ & & & \\
\hline _BNI-C & $8.67 \mathrm{E}+11$ & & & \\
\hline _MAYBANK-C & - & & & \\
\hline _BJB-C & $2.58 \mathrm{E}+11$ & & & \\
\hline
\end{tabular}

Sumber: Output E-Views 9.0

Berdasarkan tabel di atas menunjukkan nilai t-statistik X sebesar 2.710368 dan nilai probabilitas sebesar 0.0075 . dengan menggunakan tingkat keyakinan $\alpha=5 \%$, sehingga dapat disimpulkan bahwa Ho ditolak dan Ha diterima, artinya variabel tingkat suku bunga Bank Indonesia berpengaruh signifikan terhadap pendapatan margin murabahah pada Bank Umum Syariah periode 2017-2018.

Tabel 1.11

Hasil Uji Koefisien Determinasi

\begin{tabular}{|c|c|c|c|}
\hline \multicolumn{4}{|c|}{ Dependent Variable: PENDAPATAN? } \\
\hline \multicolumn{4}{|c|}{ Method: Pooled EGLS (Cross-section random effects) } \\
\hline \multicolumn{4}{|c|}{ Date: $03 / 03 / 20$ Time: $16: 44$} \\
\hline \multicolumn{4}{|c|}{ Sample: 2017M01 2018M12 } \\
\hline \multicolumn{4}{|c|}{ Included observations: 24} \\
\hline \multicolumn{4}{|c|}{ Cross-sections included: 6} \\
\hline \multicolumn{4}{|c|}{ Total pool (balanced) observations: 144} \\
\hline \multicolumn{4}{|c|}{ Swamy and Arora estimator of component variances } \\
\hline & & & \\
\hline & \multirow{2}{*}{\multicolumn{2}{|c|}{ Weighted Statistics }} & \\
\hline & & & \\
\hline R-squared & 0.049188 & Mean dependent var & $3.36 \mathrm{E}+10$ \\
\hline Adjusted R-squared & 0.042493 & S.D. dependent var & $2.67 \mathrm{E}+11$ \\
\hline S.E. of regression & $2.61 \mathrm{E}+11$ & Sum squared resid & $9.68 \mathrm{E}+24$ \\
\hline F-statistic & 7.346095 & Durbin-Watson stat & 0.498665 \\
\hline Prob(F-statistic) & 0.007550 & & \\
\hline
\end{tabular}

Sumber: Output E-Views 9.0

Berdasarkan tabel di atas, koefisien determinasi ( $\mathrm{R}$ Square) $=0.049188$ Artinya sumbangan variabel $\mathrm{X}$ terhadap variabel $\mathrm{Y}$ sebesar 4,9\% sedangkan sisanya $95,1 \%$ disumbangkan oleh variabel lain. 
Berdasarkan hasil estimasi model regresi menggunakan model random effect yang telah dilakukan, adapun persamaan regresi yang diperoleh yaitu: $Y=100968871354 *$ BIRATE - 208397396914, hal ini berarti Jika X bernilai 5, maka Y bernilai 296446959856 (296.446.959.856 = dua ratus sembilan puluh enam miliar empat ratus empat puluh enam juta sembilan ratus lima puluh sembilan ribu delapan ratus lima puluh enam rupiah).

Koefisien estimasi X terhadap Y sebesar 100968871354 (100.968.871.354 = seratus miliar sembilan ratus enam puluh delapan juta delapan ratus tujuh puluh satu ribu tiga ratus lima puluh empat rupiah). Hal ini berarti setiap kenaikan 1\% tingkat suku bunga bank Indonesia akan meningkatkan pendapatan margin murabahah sebesar 100968871354, begitupun jika nilai X turun sebesar 100968871354 satu-satuan maka nilai Y akan turun sebesar 100968871354 . Koefisien estimasi X juga bernilai positif, itu artinya apabila X naik maka Y juga akan naik.

Hasil uji hipotesis setelah diuji menggunakan uji t menunjukkan adanya pengaruh antara tingkat suku bunga Bank Indonesia terhadap pendapatan margin murabahah. Hal ini dapat dibuktikan dari nilai koefisien variabel independen (tingkat suku bunga Bank Indonesia) yang menunjukkan nilai probabilitas sebesar 0.0075 dengan menggunakan tingkat keyakinan $\alpha=5 \%$, sehingga dapat disimpulkan bahwa Ho ditolak dan Ha diterima, artinya variabel tingkat suku bunga Bank Indonesia berpengaruh signifikan terhadap pendapatan margin murabahah pada Bank Umum Syariah di Indonesia periode 2017-2018.

Adanya pengaruh dari tingkat suku bunga Bank Indonesia terhadap pendapatan margin murabahah membuktikan bahwa sistem bunga masih membayang-bayangi bank syariah mengingat bank syariah beroperasional di dalam sebuah lingkungan industri perbankan yang didominasi oleh sistem bunga. Karena hal inilah Bank Umum Syariah di Indonesia dalam menyalurkan pembiayaan murabahah masih menjadikan tingkat suku bunga sebagai acuan dan sarana perbandingan dalam menetapkan margin. Bank Umum Syariah juga masih berada dalam lingkup Bank Indonesia dimana ada dua jenis bank di dalamnya yaitu bank konvensional dan bank syariah.

Dari hasil uji menggunakan analisis regresi data panel dengan pendekatan random effect yang telah peneliti lakukan, Penelitian ini membuktikan kebenaran dan konsistensi dari teori yang disampaikan oleh Muhammad dan Karim.

Adapun hasil dari analisis koefisien determinasi menunjukkan bahwa besarnya koefisien korelasi (R Square) adalah 0.049188 Artinya sumbangan variabel X (tingkat suku bunga Bank Indonesia) terhadap variabel Y (pendapatan margin murabahah) sebesar 4,9\% sedangkan sisanya 95,1\% disumbangkan oleh variabel lain yang tidak diteliti dalam penelitian ini.

Dengan nilai rasio 4,9\% dari hasil uji koefisien determinasi di atas menunjukkan bahwa pengaruh variabel tingkat suku bunga Bank Indonesia terhadap pendapatan margin murabahah masuk dalam kategori kecil karena Menurut Muhammad faktor-faktor yang mempengaruhi pendapatan margin murabahah ada 6 yaitu: Kebutuhan bank syariah untuk memperoleh keuntungan riil, Inflasi, Suku bunga berjalan, Kebijakan moneter, Marketabilitas barang-barang murabahah, dan Tingkat laba yang diharapkan.

Jadi seharusnya pengaruh yang ditimbulkan dari keenam faktor di atas biasanya berada di kisaran $16-17 \%$ (100 : 6). Dari proporsi 4,9\% dari variabel X tersebut bisa dikategorikan kecil.

Adiwarman Karim dalam bukunya juga menyebutkan bahwa penetapan margin keuntungan bank syariah berdasarkan rekomendasi, usulan dan saran dari Tim ALCO (Assets and Loss Committe) bank syariah dengan mempertimbangkan salah satunya adalah Indirect Competitor's Market Rate (ICMR). ICMR adalah tingkat suku bunga rata-rata perbankan konvensional atau tingkat rata-rata suku bunga beberapa bank konvensional yang dalam rapat ALCO ditetapkan sebagai kelompok kompetitor tidak langsung, atau rata-rata suku bunga bank konvensional tertentu yang dalam rapat ALCO ditetapkan sebagai kompetitor 
tidal langsung yang terdekat. Jadi, tingkat suku bunga Bank Indonesia merupakan salah satu acuan bank syariah dalam menetapkan margin murabahah.

Dari pemaparan di atas, dapat kita simpulkan bahwa Bank Umum Syariah di Indonesia dalam menyalurkan pembiayaan murabahah masih dipengaruhi oleh bayangbayang tingkat suku bunga karena Bank Umum Syariah menjadikan tingkat suku bunga sebagai acuan dan sarana perbandingan dalam menetapkan margin. Bank Umum Syariah juga masih berada dalam lingkup Bank Indonesia dimana ada dua jenis bank di dalamnya yaitu bank konvensional dan bank syariah.

Hasil penelitian ini mendukung penelitian yang dilakukan oleh Anik dengan judul penelitian "faktor yang berpengaruh terhadap margin murabahah pada Bank Syariah Mandiri Periode 2013-2015" dimana hasil penelitiannya menunjukkan bahwa nilai koefisien sebesar 65.169 dengan tingkat signifikansi 0,003. Variabel ini memiliki tingkat signifikansi lebih kecil dari 0,05 yang artinya Ho ditolak dan Ha diterima sehingga variabel BI Rate berpengaruh terhadap pendapatan margin murabahah.

Namun penelitian ini bertentangan dengan penelitian yang dilakukan oleh Fifi Hakimi dengan judul penelitian "pengaruh FDR, NPF, biaya operasional, inflasi, dan BI Rate terhadap margin pembiayaan murabahah (studi kasus BPRS Bangun Drajat Warga Periode 20092016)" dimana hasil penelitiannya menunjukkan bahwa nilai thitung sebesar 0,236 lebih kecil dari nilai ttabel sebesar 1,695 dengan nilai signifikan $0,815>0,05$, artinya variabel BI rate tidak berpengaruh signifikan terhadap penetapan margin murabahah.

\section{PENUTUP}

\section{a. Kesimpulan}

Berdasarkan hasil pembahasan di atas, maka dapat ditarik kesimpulan sebagai berikut:

1. Dari hasil estimasi Random Effect Model (REM) menggunakan program E-Views 9.0 menghasilkan analisis uji t yang menunjukkan adanya pengaruh antara tingkat suku bunga Bank Indonesia terhadap pendapatan margin murabahah. Hal ini dapat dibuktikan dari nilai koefisien variabel independen (tingkat suku bunga Bank Indonesia) yang menunjukkan nilai probabilitas sebesar 0.0075 dengan menggunakan tingkat keyakinan $\alpha=5 \%(0.0075<0.05)$ dengan persamaan regresi $\mathrm{Y}=100968871354 *$ BIRATE -208397396914 sehingga dapat disimpulkan bahwa Ho ditolak dan Ha diterima, artinya variabel tingkat suku bunga Bank Indonesia berpengaruh signifikan terhadap pendapatan margin murabahah pada Bank Umum Syariah periode 2017-2018.

2. Dari analisis koefisien determinasi ( $\mathrm{r} 2$ ) diketahui bahwa besarnya $\mathrm{R}$ Square adalah 0.049188, Artinya sumbangan variabel X (tingkat suku bunga Bank Indonesia) terhadap variabel Y (pendapatan margin murabahah) sebesar 4,9\% sedangkan sisanya 95,1\% disumbangkan atau dipengaruhi oleh variabel lain yang tidak diteliti dalam penelitian ini.

\section{b. Saran}

Berdasarkan hasil penelitian yang telah dipaparkan di atas, maka selanjutnya peneliti menyampaikan saran-saran yang sekiranya dapat bermanfaat kepada pihak-pihak yang terkait atas penelitian ini. Adapun saran-saran tersebut adalah sebagai berikut:

1. Bagi peneliti selanjutnya diharapkan bisa memperluas lagi dengan menambah periode penelitian dan variabel lain yang dapat mempengaruhi pendapatan margin murabahah.

2. Bagi Bank Umum Syariah agar mengkaji kembali perhitungan margin murabahah dan dalam menetapkan margin murabahah sebaiknya tidak lebih besar dari pada tingkat suku bunga yang ditetapkan. 
Ali, Herni, dan M Miftahurrohman. “Analisis Pengaruh Dana Pihak Ketiga (DPK), Non Performing Financing dan Tingkat Suku Bunga Kredit Terhadap Pembiayaan Berbasis Bagi Hasil (Mudharabah) Pada Perbankan Syariah di Indonesia." Tauhidinomics: Journal of Islamic Banking and Economics 1, no. 2 (2015): 5-166. https://doi.org/10.15408/thd.v1i2.8432.

Arumdhani, Astri, dan Rini Septiani. "Pengaruh Pembiayaan Murabahah Dan Tingkat Suku Bunga BI Terhadap Pendapatan Margin Murabahah Pada PT Bank Syariah Mandiri." Jurnal Riset Akuntansi 4, no. 1 (2012): 27-46.

Baltagi, Badi H. Econometric Analysis of Panel Data. 3 ed. Southern Gate: John Wiley \& Sons, 2005.

Djalal, Nachrowi N, dan Hardius Usman. Pendekatan Populer dan Praktis Ekonomi dan Keuangan. Jakarta: LPFE Universitas Indonesia, 2006.

Fakhriana, Agus. "Pengaruh Suku Bunga Kredit dan Deposito Bank Konvensional Terhadap Margin Pembiayaan Murabahah Bank Syariah di Indonesia." Jurnal Penelitian 2, no. 1 (2015): 39-54. https://doi.org/10.28918/jupe.v12i1.642.

Hakimi, Fifi. "Pengaruh FDR, NPF, Biaya Operasional, Inflasi, dan BI Rate Terhadap Margin Pembiayaan Murabahah (Studi Kasus BPRS Bangun Drajat Warga Periode 2019-2016).” Naskah Publikasi, 2017.

Hasan, Iqbal. Analisis Data Penelitian Dengan Statistik. Jakarta: PT Bumi Aksara, 2010.

Karim, Adiwarman A. Bank Islam: Analisis Fiqih Dan Keuangan. Jakarta: PT Raja Grafindo Persada, 2013.

Kasiram, Moh. Metode Penelitian Kualitatif-Kuantitatif. Malang: UIN Maliki Press, 2010.

Kasmir. Dasar-dasar Perbankan. Jakarta: Rajawali Press, 2014.

Kurniawan, Albert. Metode Riset Untuk Ekonomi \& Bisnis. Bandung: Alfabeta, 2014.

Martono, Nanang. Metode Penelitian Kuantitatif Analisis Isi dan Analisis Data Sekunder. Jakarta: Rajawali Pers, 2011.

Muhamad. Manajemen Bank Syariah. Yogyakarta: UPP STIM YKPN, 2018.

—. Manajemen Pembiayaan Bank Syariah. Yogyakarta: UPP STIM YKPN, 2016.

Nuryana, Fatati. Statistik Bisnis Jilid I. Surabaya: Pena Salsabila, 2013.

Otoritas Jasa Keuangan. "Statistik Perbankan Syariah 2019," t.t. https://www.ojk.co.id.

Santoso, Singgih. Statistik Multivariat. Jakarta: PT Elex Media Komputindo, 2010. 
Sejarweni, V. Wiratna, dan Poly Endrayanto. Statistik Untuk Penelitian. Yogyakarta: Graha Ilmu, 2012.

Sugiyono. Metode Penelitian Kuantitatif Kualitatif dan R\&D. Bandung: CV.Alfabeta, 2006.

Umar, Husein. Metode Penelitian untuk Skripsi dan Tesis Bisnis. Jakarta: Rajawali Pers, 2013.

Wicaksono, Rianto Anugerah. "Pengaruh Perubahan Tingkat Suku Bunga Kredit Bank Konvensional dan Tingkat Suku Bunga Bank Indonesia Terhadap Pembiayaan Bank Islam Berbasis Murabahah.” Jurnal Publikasi Manajemen 13, no. 3 (2015): 494-501.

Widarjono, Agus. Ekonometrika: Teori dan Aplikasi Untuk Ekonomi dan Bisnis Edisi Kedua. Yogyakarta: Ekonisia FE Universitas Islam Indonesia, 2007.

Widodo, Sugeng. Pembiayaan Murabahah. Yogyakarta: UII Press, 2017. 